\title{
Protective Effect of Allium cepa (Onion) Seeds (AC) Extract on Histopathology of Testis in STZ-Induced Male Rats
}

\author{
Efecto Protector del Extracto de Semillas de Allium cepa (Cebolla) (AC) \\ en la Histopatología del Testículo en Ratas Macho Inducidas por STZ
}

Vajihe Fallah $^{1}$; Javad Amini Mahabadi ${ }^{1}$; Mahshid Yaghmaeian Mahabadi ${ }^{1}$ Hamed Haddad Kashani² \& Hossein Nikzad $^{1}$

FALLAH, V.; MAHABADI, J. A.; MAHABADI, M. Y.; KASHANI, H. H. \& NIKZAD, N. Protective effect of Allium cepa (onion) seeds (AC) extract on histopathology of testis in stz-induced male rats. Int. J. Morphol., 35(4):1517-1524, 2017.

SUMMARY: The aim of the present study was to evaluate the effect of the extract of Allium cepa (Onion) seeds (AC) on morphometric and histology of testis and biochemical parameters in STZ-induced male rats. Forty adult male Wistar rats (2 month old) were allocated into four groups of control, diabetic control, diabetic treated with $200 \mathrm{or} 400 \mathrm{mg} / \mathrm{kg} / \mathrm{day}$ of onion seed extract. Diabetes mellitus was induced using $60 \mathrm{mg} / \mathrm{kg}$ body weight of Streptozotocin as a single intraperitoneal injection. The extract was administered by stomach gavage for 28 days. The morphometric and histological structure of the testis, biochemical factors like glucose and testosterone levels were assessed. All analyses were done at the end of the four week study period. Data were compared by using Kruskal Wallis Test, Dunnett T3 and the degree of significance was set at $\mathrm{P}<0.05$ and $\mathrm{P}<0.01$. In diabetic +200 rats, the numbers of primary spermatocytes were significantly increased. In diabetic +400 rats, seminiferous tubular diameter was significantly increased and the level of testosterone hormone and testis weight was decreased significantly. In diabetic+200 and 400 rats, the numbers of spermatid, FBS and lumen diameter were significantly increased and the numbers of spermatozoa cells, body weight and volume density (VD) \% lumen were decreased. Also, the numbers of spermatid in control diabetic rats was decreased. Our finding indicated that onion seed extract might be useful as a supplementary protective agent against adverse effects of diabetes on reproductive system in diabetic men.

KEY WORDS: Onion, Testis, Rat, Streptozotocin, Histopathology.

\section{INTRODUCTION}

Diabetes mellitus (DM) is defined as abnormality of carbohydrate metabolism, which is related to low blood insulin level or insensitivity of target organs to insulin. DM is either inherited and/or acquired deficiency in the production of insulin by the pancreas or by the inefficiency of the insulin produced (Maiti et al., 2004). This disease is associated with reduced quality of life and increased risk factors for mortality and morbidity, therefore requiring medical diagnosis and treatment as well as changes in life style (Amorim et al., 2011). Several studies showed that hyperglycemia and oxidative stress play a significant role in diabetic tissue damage (Rabbani et al., 2009).

Diabetes has been associated with reproductive disability in both men and women. About $90 \%$ of diabetic patients have disturbances in sexual function, epidemic metabolic disease, which provokes severe detrimental blood testis barrier (BTB) alterations leading to a decreased fertility rates (Alves et al., 2013). Infertile male diabetics tend to suffer from decreased sex libido, diminishing sperm count, endocrine disturbance, impaired penile erection and ejaculation (Zhao et al., 2010).

At present, different methods including synthetic antidiabetic drugs and also lifestyle modification are used to manage DM. Synthetic drugs include sulphonylureas (glibenclamide), glucosidase inhibitors (acarbose), and iguanide (metformin). However, these synthetic oral hypoglycemic agents have characteristic profiles of serious side effects, which include hypoglycemia, weight gain, gastrointestinal irritation, nausea, liver and heart failure, and diarrhea (Abdel-Rahman, 2006). So due to the lower side effects, there is a growing interest in herbal remedies for the treatment of diabetes mellitus (Cai et al., 2013).

\footnotetext{
${ }^{1}$ Gametogenesis Research Center, Kashan University of Medical Sciences, Kashan, Iran.

${ }^{2}$ Anatomical Sciences Research Center, Kashan University of Medical Sciences, Kashan, Iran.
} 
Allium cepa (Alliaceae): The onion (Allium cepa) has long been used in traditional medicine, is one of the important Allium species commonly used in our daily diet, and has recently been the source of much interest because of its antithrombotic, hypolipidaemic, hypotensive, diaphoretic, antibiotic, antidiabetic, antiatherogenic, and anticancer medicinal properties (Lee et al., 2008).

The antidiabetic effect of A. cepa L. (Liliaceae) was evaluated in both animal models and human subjects (Taj Eldin et al., 2010). Furthermore, the role of nutritional factors in reproduction and subfertility is important. The results of a study showed that oral administration of seed extract of $A$. сера for 60 days in male albino rats could decrease the weights of reproductive organs, sperm motility, sperm count and androgen dependent parameters but could increase the serum cholesterol level (Venkatesh et al., 2002).

Various compounds were isolated and correlated positively as being responsible for the hypoglycemic effect of A. cepa. Phenolics and sulphur compounds, such as cysteine and allyl propyldisulphide, have been associated with this effect (Taj Eldin et al.). A. cepa also known to have antioxidants such as selenium, glutathione, vitamins $\mathrm{A}, \mathrm{B}, \mathrm{C}$ and flavonoids such as quercetin and isorhamnetin (Griffiths et al., 2002).

The present research was designed to investigate the protective effect of the extract of Allium cepa (Onion) seeds (AC) on histopathological studies of testis in STZ-induced male rats.

\section{MATERIAL AND METHOD}

Selection of Animal and Animal Care: Adult males Wistar rats of 2 months age and weighing 150-200 gr were housed in Animal House Lab with an ambient temperature of $25 \pm 2$ ${ }^{\circ} \mathrm{C}$ with $12 \mathrm{~h}$ light: $12 \mathrm{~h}$ dark cycle. Rats had free access to standard food and water ad libitum. The principles of laboratory animal care (NIH 1985) and all the instruction given by Kashan University of Science ethical committee were followed throughout the experimentation.

Induction and estimation of diabetes (diabetic animals): In this study, streptozotocin (STZ, Sigma-Aldrich, USA) was used to produce experimental diabetes mellitus. A single dose of $60 \mathrm{mg} / \mathrm{kg}$ body weight of STZ was freshly prepared in cold $0.1 \mathrm{~mol} /$ lit citrate buffer, $\mathrm{PH} 4.5$, and injected intraperitoneally to induce DM. Then $5 \%$ glucose solution was administrated during the first 24 hours following STZ injection to prevent early mortalities.
Diabetes was confirmed with two consecutive measurements after 3 and 6 days of STZ injection. The rats with fasting glucose level (after 14 hours) of above 200 $\mathrm{mg} / \mathrm{d} 1$ were selected and used for the present study (Kuhad et al., 2008; Abeeleh et al., 2009). Blood samples were collected from the tip of tail and fasting blood glucose levels were measured by using glucometer (On Call ${ }^{\circledR}$ Plus, USA).

Onion seed extract: In our study Onion seed was obtained from Barij Essence Company in Kashan, Iran. To prepare the alcoholic extract, $500 \mathrm{gr}$ of onion seeds was grinded and merged completely in $96 \%$ ethanol for 24 hours. The mixture was filtered; ethanol was added for another 12 hours and filtered again. The filtrate was dried in $50^{\circ} \mathrm{C}$ oven. The dried extract was weighted and solutions of 100 and $200 \mathrm{mg} / \mathrm{ml}$ were prepared and stored at $4{ }^{\circ} \mathrm{C}$ until use.

Experimental design: Male rats were randomly divided into four groups $(n=10)$. Group 1 was normal control animals that received an intraperitoneal injection of normal citrate buffer. Group 2 were diabetic control group that were diabetic with no treatment. Group 3 and 4 were diabetic rats treated with 200 or $400 \mathrm{mg} / \mathrm{kg} /$ day of onion seeds extract respectively. The extract was administered by stomach gavage for 28 days. At the end of four weeks treatment, animals were weighted and sacrificed. Blood sample was collected from the heart into centrifuge tubes and allowed to clot for 30 minutes at room temperature. Blood samples were centrifuged at $3000 \mathrm{rpm}$ for 20 minutes and serum was separated and stored at $-20^{\circ} \mathrm{C}$ for further analysis.

Biochemical studies: Serum samples were analyzed for glucose and testosterone.

Histology: Testis of the rats were separated, weighted and then fixed in Bouin's solution for histological examination. The fixed samples were processed in an Autotechnicon Tissue Processor to prepare paraffin blocks. Five micron microscopic sections of the block were stained with Haematoxylin and Eosin (H\&E) for light microscopy examinations.

\section{Morphometric studies:}

Quantification of Germ Cells at Stages VII and VIII in Seminiferous Epithelial Cycle: The H\&E stained slides were examined under a light microscope (Zeiss/German) and different cells (sustentacular or sertoli, Spermatogonia [Sg], Primary Spermatocytes [Sc], Spermatid and Spermatozoid) present at this stage were counted with an objective lens $\times 40$. Five different round seminiferous tubules were used to calculate the average number of each cell type for each rat. 


\begin{abstract}
Seminiferous tubular diameter (STD), luminar diameter (SLD) and epithelium thickness (ET): Using an Inverted Microscope (Nikon Inverted Microscope Eclipse Ti with DS camera control Unit Ds-L2) at least 15 round or nearly round tubules were used to calculate the average size of tubular diameter, Luminar Diameter and epithelium thickness. The mean value of each parameter was calculated as the average of two measurements at right angle.
\end{abstract}

Volume density (VD): A point-counting method was used to measure the volume density of lumen, epithelium and interstitial tissue. The volume density was obtained by dividing the number of points on a tissue compartment (PN) on the total number of points (Ptn) that was 700 in our study. Volume density determined by multiplication in $100(\%)$.

$$
\mathrm{VD}(\%)=\frac{\mathrm{pN}}{\mathrm{Ptn}} \times 100
$$

Statistical analysis: Kruskal Wallis and Dunnett T3 test were used for statistical analysis using SPSS software (version 16). Results were reported as mean \pm S.E. and differences were considered as significant when the $\mathrm{P}$ value was less than 0.05 .

\section{RESULTS}

Animal weights: Animal weights were compared in different groups and the results showed that the control diabetic group animals had a significantly lower body weight than other groups. The onion seed extract treatment for 28 days did not recover the body weight significantly compared with the diabetic control group. Testis weight in the diabetic group treated with $400 \mathrm{mg} / \mathrm{kg}$ extract was significantly decreased compared to control or diabetic control group (Table I).

Results of blood chemistry: plasma glucose level was significantly elevated in STZ-induced diabetic rats (control diabetic) compared to normal control group. Also the level of testosterone hormone was decreased significantly in STZinduced diabetic rats as well.

Induction of diabetes caused to reduction in the level of testosterone hormone in diabetic groups, but was significant only in A. cepa 400 group in comparison to control and control diabetic groups (Table II). The administration of $400 \mathrm{mg} / \mathrm{kg}$ of A. cepa seeds extract to the diabetic animals for $28 \mathrm{~d}$ resulted in a significant recovery of the weight parameters.

Histology results: Normal rat testis slides showed a normal

Table I Effect of Allium cepa seeds extract administration on the rat body and testis weight at the beginning and end of the study.

\begin{tabular}{lcccc} 
Groups & Control & Diabetic control & A. cepa 200 & A. cepa 400 \\
\hline Pody Weight on start day & $180 \pm 12.98$ & $182.57 \pm 9.78$ & $181.14 \pm 7.08$ & $181.63 \pm 7.09$ \\
Weight at the end of study & $282 \pm 23.05$ & $204.57 \pm 31.90 \mathrm{a}^{* *}$ & $195 \pm 23.09 \mathrm{a} * *$ & $169 \pm 12.55^{\mathrm{a} * *}$ \\
Weight of testis & $1.42 \pm 0.05$ & $1.38 \pm 0.16$ & $1.33 \pm 0.10$ & $1.18 \pm 0.16^{\mathrm{ab}^{*}}$ \\
\hline
\end{tabular}

Data are presented as mean \pm SE.

a: Significant compared to control group in the same row. b: Significant compared to diabetic control group in the same row. *Significant different at $\mathrm{P}<0.05$ level. **Significant different at $\mathrm{P}<0.01$ level.

Table II. Effect of Allium cepa seeds extract administration on serum level of FBG and testosterone in rats after induction of diabetes.

control Diabetic control A. cepa $200 \quad$ A. cepa 400

\begin{tabular}{lccrr} 
Groups & & \\
\multicolumn{5}{c}{ Parameters } \\
FBG (start of study) & $89.40 \pm 13.37$ & $221.43 \pm 47.35 \mathrm{a}^{* *}$ & $241.86 \pm 37.01^{\mathrm{a}^{*} *}$ & $217 \pm 49.10 \mathrm{a}^{* *}$ \\
FBG (end of study) & $87.40 \pm 4.39$ & $340.43 \pm 117.67 \mathrm{a}^{* *}$ & $187.57 \pm 151.30$ & $118.50 \pm 61.14 \mathrm{~b}^{* *}$ \\
Testosterone (mg/ml) & $3.05 \pm 1.14$ & $2.06 \pm 1.21$ & $0.73 \pm 0.66$ & $0.55 \pm 0.477^{*} *$
\end{tabular}

Data are presented as mean \pm SE.

a: Significant compared to control group in the same row. b: Significant compared to diabetic control group in

the same row. *Significant different at $\mathrm{P}<0.05$ level. **Significant different at $\mathrm{P}<0.01$ level 
histology under a light microscope. The active mature functioning seminiferous tubules showed a complete spermatogenic series as demonstrated in Fig.1 (a, b). In contrast, the testes of STZ-induced diabetic rats revealed marked degenerated and atrophied seminiferous tubules lacking spermatogenic series and sperms in tubular lumen. Also vacuolation and exfoliation of germ cells into the lumen of seminiferous tubule were other features of the diabetic group (Fig.1, c, d). The testes of diabetic +200 showed a milder degeneration of seminiferous tubules and a partial recovery showing some normal spermatogenic series as demonstrated in Fig. 1 (e, f). Microscopic examination of the diabetic +400 testes did not show any significant improvement of testis histology compared to the control group (Fig. 1, g, h).

\section{Quantification of Germ Cells at stages VII and VIII in Seminiferous Epithelial Cycle;}

Germ cell counting results: The results of different germ cell counting are illustrated in Table III. In control diabetic rats, the number different germ cells were decreased but it was only significant for spermatid and spermatozoa cells. However in diabetic +200 rats the number of different germ cells was increased compared to diabetic group and also the number of primary spermatocyte and spermatid cells were significantly increased compared to diabetic group. But, in diabetic +400 only the number spermatid cells were increased significantly compared to the control diabetic group. Our results showed that the consumption of $A$. cepa extract (200 or 400) could not recover the decreased number of sperm count in control diabetic rats.

Results of seminiferous tubular diameter (STD), seminiferous luminar diameter (SLD), epithelium thickness (ET). Our results showed that in diabetic +200 rats the diameter of seminiferous tubules, diameter of lumen of seminiferous tubules and their germinal epithelium thickness of diabetic were increased but in diabetic +400 rats only SLD was increased significantly compared to the control diabetic group (Table IV).

Results of volume density (VD): In diabetic control group, there was a non-significant VD\% lumen increase and VD\% epithelium decrease compared to the control group. The consumption of $A$. cepa extract (both doses) could decrease significantly the average of VD\% lumen compared to diabetic control group (Table V).

Table III. Effect of Allium cepa seeds extract administration on sustentacular and germ cell count of STZ induced diabetic rats.

\begin{tabular}{lcccc} 
Groups & Control & Diabetic control & A. cepa 200 & A. cepa 400 \\
Parameters & & & $41.29 \pm 4.79$ & $41.13 \pm 5.57$ \\
\hline S permatogonia & $41.20 \pm 2.95$ & $35.00 \pm 6.48$ & $19.57 \pm 4.43$ & $16.88 \pm 1.46$ \\
S ustentacular & $15 \pm 1.41$ & $15.71 \pm 2.75$ & $51.43 \pm 4.93 \mathrm{~b}^{*}$ & $47 \pm 6.05$ \\
Primary Spermatocyte & $45.60 \pm 4.39$ & $41.29 \pm 5.88$ & $136.43 \pm 12.09 \mathrm{~b}^{*}$ & $133.38 \pm 10.68^{\mathrm{b} *}$ \\
S permatid & $135.60 \pm 12.97$ & $106.29 \pm 17.17^{\mathrm{a}^{*}}$ & $136.63 \pm 13.65^{\mathrm{a} * *}$
\end{tabular}

Data are presented as mean \pm SE.

a: Significant compared to control group in the same row. b: Significant compared to diabetic control group in the same row. *Significant different at $\mathrm{P}<0.05$ level. **Significant different at $\mathrm{P}<0.01$ level.

Table IV. Effect of Allium cepa seeds extract administration on histological parameters in seminiferous tubes STZ-induced diabetic rats. Data are presented as mean \pm SE.

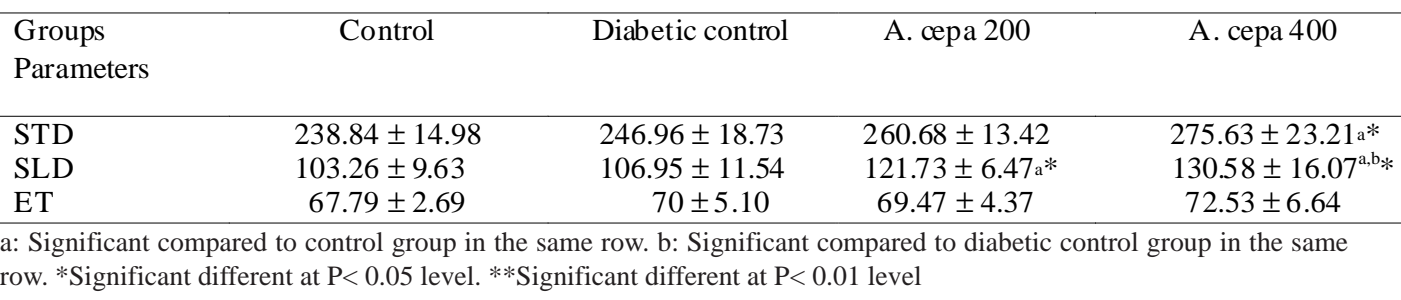


Table V. Effect of Allium cepa seeds extract administration on volume density in seminiferous tubes.

\begin{tabular}{lccll}
\multicolumn{1}{c}{ Groups } & Control & Diabetic control & A. cepa 200 & A. cepa 400 \\
Parameters & & & & \\
\hline VD\% Interstitial & $26.61 \pm 4.01$ & $26.59 \pm 5.77$ & $30.91 \pm 3.12$ & $33.37 \pm 2.76$ \\
VD\% Lumen & $25.57 \pm 0.99$ & $28.88 \pm 3.15$ & $23.84 \pm 2.53^{\mathrm{b} *}$ & $20.65 \pm 2.06^{\mathrm{ab} * *}$ \\
VD\% Epithelium & $47.82 \pm 4.39$ & $44.53 \pm 5.02$ & $45.25 \pm 3.80$ & $45.97 \pm 2.47$ \\
\hline
\end{tabular}

Data are presented as mean \pm SE. a: Significant compared to control group in the same row.

b: Significant compared to diabetic control group in the same row *Significant different at $\mathrm{P}<0.05$ level ** Significant different at $\mathrm{P}<0.01$ level
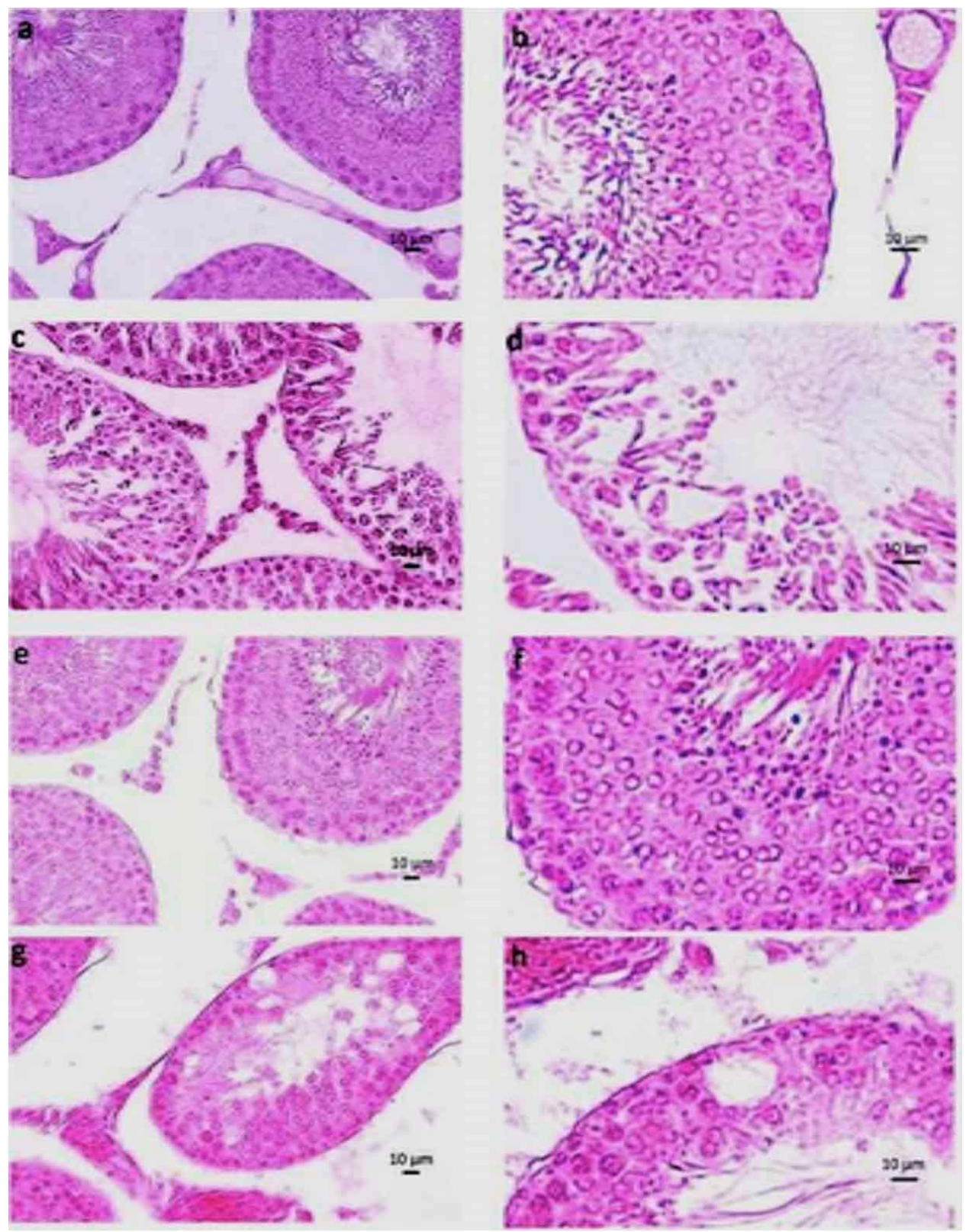

Fig. 1 (a, b) Seminiferous tubules in control group show normal histological structure. (c, d) STZinduced tubules show degeneration, a reduction in epithelium thickness, vacuolation and exfoliation of germ cells into the lumen. (e, f) The normal appearance of $A$. cepa $200 \mathrm{mg} / \mathrm{kg}$-treated tubules show this dose of seeds extract of $A$. cepa could improve the destructive effects of STZ in seminiferous tubules. (g, h) The seminiferous tubules in A. cepa $400 \mathrm{mg} / \mathrm{kg}$-treated group show this dose could not perfectly improve the destructive effects of STZ in seminiferous tubules [H\&E, 20x and $40 \mathrm{x}$ ]. 


\section{DISCUSSION}

Based on the WHO recommendations, the traditional medicine plants hypoglycemic activity are important. Although most of the diabetic traditional plants have been found to contain substances like glycosides, alkaloids, terpenoids, flavonoids, etc. that are frequently implicated as having antidiabetic effects but still there is little information about the specific modes of action in the treatment of diabetes (Mukesh \& Namita, 2013). Testicular dysfunction in diabetic patients may be transient or permanent depending on the degree and duration of the disease. Our study confirm that diabetes have an adverse effect on male reproductive function as proposed by others (Shalaby \& Mouneir, 2010). Also this study demonstrates a protective effect of the ethanol extract of Allium cepa (Onion) seeds for recovery of diabetes and testicular dysfunctions eminent in diabetic state. To our knowledge, this study is one of the few studies that evaluate the protective effects of this extract against testicular damage caused by STZ in rats.

Morphologic changes of testis biopsies from diabetic human and testis of diabetic rats were showed that increased tubule wall thickness, germ cell depletion and sustentacular cell (Sertoli cell) vacuolization in both species (Liu et al. 2011). Studies showed that testicular sperm count, motility, and testicular weight were significantly decreased in diabetic rats (Valli et al., 2015). Diabetes induced testicular damage is associated with low seminiferous tubular diameter (STD) which may be due to a low level of gonadotropins and testosterone (Castro et al. 2002). These changes may be due to DM which induces subtle molecular changes that are important for sperm quality and function and alters conventional sperm parameters. In our study, histological changes in diabetic control rats revealed degenerated and atrophied seminiferous tubules deficient of spermatogenic cells such as spermatogonia, primary spermatocyte, spermatid and spermatozoa (Fig. 1, c, d). Our results showed that administration of $200 \mathrm{mg} / \mathrm{kg}$ bw of onion seeds extract for 28 days orally resulted in an increase of seminiferous tubules with normal spermatogenic cells and significant increase in the numbers of primary spermatocyte and spermatids, compared to diabetic control group. Also this treatment could increase the number of spermatogonia and sustentacular cells as well. Sustentacular cells are somatic cells of seminiferous tubules that their support is essential for testis development and spermatogenesis. The regulation of spermatogenesis by FSH (follicle stimulating hormone) and testosterone happens through the action of these hormones on sustentacular cells. Because testosterone is necessary for spermatogenesis, FSH at least serves to promote spermatogenic output by increasing the number of sustentacular cells (Wosnitzer et al. 2014).
Our study indicated that lower dose of onion seeds extract $(200 \mathrm{mg} / \mathrm{kg} \mathrm{BW})$ could increase the number of sustentacular cells. Therefore, the increase in sustentacular cells might be one reason for the significant improvement of spermatogenesis by onion seeds extract.

In the present study, the fasting blood glucose level was reduced in the diabetic rats treated with $A$. cepa seeds extract and this effect was significant with higher dose of onion seeds extract $(400 \mathrm{mg} / \mathrm{kg} \mathrm{BW})$. Previous studies reported that oral administration of $250 \mathrm{mg} / \mathrm{kg}$ of ethanol extract of dried onion powder caused a maximal reduction of 18.57 in fasting blood glucose of alloxanized $(150 \mathrm{mg} / \mathrm{kg}$ IP) diabetic rabbit (Gupta et al. 1999).

Feeding the STZ-induced diabetic albino rats with a diet containing 3\% freeze-dried onion powder for 8 weeks produced a significant hypoglycemia along with partial reversion of abnormal plasma albumin, urea, creatinine and inorganic phosphorus (Mukesh \& Namita). The consumption of fresh crude slices ( $100 \mathrm{~g}$ ) of $A$. cepa in type 1 and 2 diabetic human subjects resulted a reduction in the blood glucose level (Taj Eldin et al.). It was also reported by El-Demerdash et al. (2005) that A. cepa at a dose of $1 \mathrm{~mL}$ or $0.4 \mathrm{~g} / 100 \mathrm{~g} \mathrm{bw}$ could restore the biochemical and antioxidant status ina T1D model of rats altered by alloxan injection (El-Demerdash $e t$ al.). Various compounds such as Phenolics and sulphur compounds, like cysteine and allyl propyldisulphide were isolated and been suggested to be responsible for the hypoglycemic effect of A. cepa (Taj Eldin et al.). Some studies have related the essential oils component to the observed hypoglycemic effects of this plant (El-Soud \& Khalil, 2010).

Diabetes induced by Streptozotocin resulted in significant reduction in prostato-somatic, seminal vesiculosomatic and testiculo-somatic indices which may be due to a low serum level of testosterone since testosterone is the prime regulator of normal growth of these organs (Kobayashi et al., 2013).

In another study, a daily administration of $0.5 \mathrm{~g} / \mathrm{rat}$ and $1 \mathrm{~g} / \mathrm{rat}$ of fresh onion juice for 20 consecutive days in non-diabetic rats significantly increased serum total testosterone (Khaki et al., 2009). But in our study it was shown that testosterone level was decreased in diabetic groups that received either dose of seeds extract of $A$. серa compared to diabetic control but it was only significant with the higher dose (400 mg/kg bw).

$\mathrm{Xu}$ et al., showed that testicular weight were significantly decreased in diabetic rats (Cai et al.). But in our study, induction of diabetes didn't change testes weight 
significantly, but administration of the higher dose of onion seeds extract could decrease testes weight. Overall our findings suggest that $A$. cepa seeds extract with dose 200 $\mathrm{mg} / \mathrm{kg}$ bw could significantly improve the spermatogenesis cycle in diabetic rats whereas the higher dose $(400 \mathrm{mg} / \mathrm{kg}$ bw) not only did not improve but even worsen the cycle of spermatogenesis in diabetic rats in compared to diabetic control group.

In another study, Venkatesh et al. showed that, the oral consumption of seed extract of Allium cepa (50 mg/ day/rat) by male albino rats for 60 days caused a significant reduction in the weights of reproductive organs: testis $(\mathrm{P}<0.001)$, epididymis $(\mathrm{P}<0.001)$, vas deferens $(\mathrm{P}<0.05)$, seminal vesicle $(\mathrm{P}<0.001)$ and ventral prostate $(\mathrm{P}<0.05)$ (Venkatesh et al.). In this study a significant decrease was also noticed in the sperm density of cauda epididymis $(\mathrm{p}<0.001)$ and testis $(\mathrm{P}<0.001)$ of the treated rats with $A$. cepa seed extract. A. cepa seed extract treatment also showed a significant reduction in the protein contents and sialic acid concentration of testis $(\mathrm{P}<0.01)$ and cauda epididymis $(\mathrm{P}<0.001)$. Also the fructose concentration of seminal vesicle was diminished significantly in treated animals. A decrease in the above androgen dependent parameters (protein, sialic acid and fructose) supports the fact that the circulating androgen level is depleted as a result of the treatment. In addition the cholesterol content of adrenal and testis increased significantly by onion seed extract as well. Treatment of A. cepa also caused a significant increase in the serum cholesterol concentration $(\mathrm{P}<0.01)$ while the concentrations of VLDL $(\mathrm{P}<0.01)$, triglycerides $(\mathrm{P}<0.01)$, albumin $(\mathrm{P}<0.05), \mathrm{A} / \mathrm{G}$ ratio $(\mathrm{P}<0.05)$ were significantly declined. Increased concentration of testicular and serum cholesterol may be correlated with non-utilization of testicular gland with normal activity in the system.

\section{CONCLUSION}

This is the first study that evaluated the protective effect of Allium cepa seed extract on testis histology in STZ-induced diabetic rats. The finding of our study indicated that Allium cepa seed extract could recover the reverse effects of diabetes disease, the testis histology parameters through preventing oxidative stress. The result of this study emphasis the use of Allium cepa as powerful source of antioxidant supplementary food in diabetic men but it can't replace insulin in treatment of diabetics. Also these results suggest further studies to use Allium cepa seed as drug to protect patients from the side effects of diabetes disease.

\section{ACKNOWLEDGEMENTS}

This study was financially supported by the deputy of research in Kashan University of Medical Science and Kashan Gametogenesis Research Center (Grant No 9110). The authors gratefully acknowledge the kind cooperation of all staff in the Gametogenesis Research Center, Kashan University of Medical Science.

FALLAH, V.; MAHABADI, J. A.; MAHABADI, M. Y.; KASHANI, H. H. \& NIKZAD, N. Efecto protector del extracto de semillas de Allium cepa (cebolla) (AC) en la histopatología del testículo en ratas macho inducidas por STZ. Int. J. Morphol., 35(4):1517-1524, 2017.

RESUMEN: El objetivo del presente estudio fue evaluar el efecto del extracto de semillas de Allium cepa (cebolla) sobre la morfometría e histología de testículos y parámetros bioquímicos en ratas macho inducidas por estreptozotocina (STZ). Se asignaron cuarenta ratas macho Wistar adultas ( 2 meses de edad) en cuatro grupos: control diabético y diabético tratados con 200 o $400 \mathrm{mg} / \mathrm{kg} /$ día de extracto de semilla de cebolla. Se indujo diabetes mellitus utilizando $60 \mathrm{mg} / \mathrm{kg}$ de peso corporal de estreptozotocina por inyección única intraperitoneal. El extracto se administró por sonda gástrica durante 28 días. Se evaluaron la estructura morfométrica e histológica de los testículos, factores bioquímicos como la glucosa y los niveles de testosterona. Todos los análisis se realizaron al final del período de estudio de cuatro semanas. Los datos se compararon mediante el uso de Kruskal Wallis Test, Dunnett T3 y el grado de significación se estableció en $\mathrm{P}<0,05$ y $\mathrm{P}<0,01$. En el grupo diabético +200 , el número de espermatocitos primarios aumentó significativamente. En el grupo diabético +400 , el diámetro tubular seminífero aumentó significativamente en cambio el nivel de testosterona y el peso del testículo disminuyeron significativamente. En el grupo diabéticos + 200 y 400, los números de espermátidas, FBS y diámetro de luz se incrementaron significativamente y el número de espermatozoides, peso corporal y densidad de volumen (VD)\% de lumen disminuyeron. Además, disminuyó el número de espermátidas en ratas diabéticas control. Nuestro estudio indicó que el extracto de semilla de cebolla podría ser útil como un agente protector adicional contra los efectos adversos de la diabetes en el sistema reproductivo en hombres diabéticos.

PALABRAS CLAVE: Cebolla; Testículo; Rata; Estreptozotocina; Histopatología.

\section{REFERENCES}

Abdel-Rahman, M. K. Effect of pumpkin seed (Cucurbita pepo L.) diets on benign prostatic hyperplasia (BPH): Chemical and morphometric evaluation in rats. World J. Chem., 1(1):33-40, 2006.

Abeeleh, M. A.; Ismail, Z. B.; Alzaben, K. R.; Abu-Halaweh, S. A.; Al- 
Essa, M. K.; Abuabeeleh, J. \& Alsmady, M. M. Induction of diabetes mellitus in rats using intraperitoneal streptozotocin: a comparison between 2 strains of rats. Eur. J. Sci. Res., 32(3):398-402, 2009.

Alves, M. G.; Martins, A. D.; Cavaco, J. E.; Socorro, S. \& Oliveira, P. F. Diabetes, insulin-mediated glucose metabolism and Sertoli/bloodtestis barrier function. Tissue Barriers, 1(2):E23992, 2013.

Amorim, E. M.; Damasceno, D. C.; Perobelli, J. E.; Spadotto, R.; Fernandez, C. D.; Volpato, G. T. \& Kempinas, W. D. Short- and longterm reproductive effects of prenatal and lactational growth restriction caused by maternal diabetes in male rats. Reprod. Biol. Endocrinol., 9:154, 2011.

Cai, H.; Xia, X.; Wang, L.; Liu, Y.; He, Z.; Guo, Q. \& Xu, C. In vitro and in vivo differentiation of induced pluripotent stem cells into male germ cells. Biochem. Biophys. Res. Commun., 433(3):286-91, 2013.

Castro, A. C. S.; Berndtson, W. E. \& Cardoso, F. M. Plasma and testicular testosterone levels, volume density and number of Leydig cells and spermatogenic efficiency of rabbits. Braz. J. Med. Biol. Res., 35(4):493-8, 2002

El-Demerdash, F. M.; Yousef, M. I. \& El-Naga, N. I. A. Biochemical study on the hypoglycemic effects of onion and garlic in alloxaninduced diabetic rats. Food Chem. Toxicol., 43(1):57-63, 2005.

El-Soud, N. \& Khalil, M. Antioxidative effects of Allium cepa essential oil in streptozotocin induced diabetic rats. Maced. J. Med. Sci., 3(4):344-51, 2010.

Taj Eldin, I. M.; Ahmed, E. M. \& Elwahab, H. M. A. E. Preliminary study of the clinical hypoglycemic effects of Allium cepa (red onion) in type 1 and type 2 diabetic patients. Environ. Health Insights, 4:717, 2010

Griffiths, G.; Trueman, L.; Crowther, T.; Thomas, B. \& Smith, B. Onions-a global benefit to health. Phytother. Res., 16(7):603-15, 2002.

Gupta, D.; Raju, J. \& Baquer, N. Z. Modulation of some gluconeogenic enzyme activities in diabetic rat liver and kidney: effect of antidiabetic compounds. Indian J. Exp. Biol., 37(2):196-9, 1999.

Khaki, A.; Fathiazad, F.; Nouri, M.; Khaki, A. A.; Khamenehi, H. \& Hamadeh, M. Evaluation of androgenic activity of Allium cepa on spermatogenesis in the rat. Folia Morphol. (Warsz.), 68(1):45-51, 2009.

Kobayashi, H.; Nagao, K. \& Nakajima, K. Therapeutic advances in the field of male infertility: Stem cell research. Adv. Stud. Med. Sci., 1(1):39-54, 2013

Kuhad, A.; Sethi, R. \& Chopra, K. Lycopene attenuates diabetesassociated cognitive decline in rats. Life Sci., 83(3-4):128-34, 2008.

Lee, S. U.; Lee, J. H.; Choi, S. H.; Lee, J. S.; Ohnisi-Kameyama, M.; Kozukue, N.; Levin, C. E. \& Friedman, M. Flavonoid content in fresh, home-processed, and light-exposed onions and in dehydrated commercial onion products. J. Agric. Food Chem., 56(18):8541-8, 2008.

Liu, S. P.; Fu, R. H.; Huang, Y. C.; Chen, S. Y.; Chien, Y. J.; Hsu, C. Y.; Tsai, C. H.; Shyu, W. C. \& Lin, S. Z. Induced pluripotent stem (iPS) cell research overview. Cell Transplant., 20(1):15-9, 2011.

Maiti, R.; Jana, D.; Das, U. K. \& Ghosh, D. Antidiabetic effect of aqueous extract of seed of Tamarindus indica in streptozotocin-induced diabetic rats. J. Ethnopharmacol., 92(1):85-91, 2004.

Mukesh, R. \& Namita, P. Medicinal plants with antidiabetic potential - A review. Am. Eurasian J. Agric. Environ. Sci., 13(1):81-94, 2013.

Rabbani, S. I.; Devi, K. \& Khanam, S. Inhibitory effect of glimepiride on nicotinamide-streptozotocin induced nuclear damages and sperm abnormality in diabetic Wistar rats. Indian J. Exp. Biol., 47(10):80410, 2009.

Shalaby, M. \& Mouneir, S. M. Effect of zingiber officinale roots and cinnamon zeylanicum bark on fertility of male diabetic rats. Glob. Vet., 5(6):341-7, 2010.

Valli, H.; Gassei, K. \& Orwig, K. E. Stem cell therapies for male infertility: Where are we now and where are we going? In: Carrell, D.; Schlegel, P.; Racowsky, C. \& Gianaroli, L. (Eds.). Biennial Review of Infertility. Cham, Springer, 2015. pp.17-39.
Venkatesh, V.; Sharma, J. D. \& Kamal, R. A comparative study of effect of alcoholic extracts of Sapindus emarginatus, Terminalia belerica, Cuminum cyminum and Allium cepa on reproductive organs of male albino rats. Asian J. Exp. Sci., 16(1-2):51-63, 2002.

Wosnitzer, M.; Goldstein, M. \& Hardy, M. P. Review of azoospermia. Spermatogenesis, 4(1):e28218, 2014.

Zhao, X.; Zhong, J.; Mo, Y.; Chen, X.; Chen, Y. \& Yang, D. Association of biochemical hyperandrogenism with type 2 diabetes and obesity in Chinese women with polycystic ovary syndrome. Int. J. Gynaecol. Obstet., 108(2):148-51, 2010.

\section{Corresponding author:}

Dr. Hossein Nikzad

Gametogenesis Research Center

Kashan University of Medical Sciences

Kashan

IRAN

\section{E-mail: hosseinnikzad43@yahoo.com nikzad_h@kaums.ac.ir}

Tel : +98-31-55621158

Fax: +98-21-55621157

Received:11-10-2016

Accepted:04-07-2017 